УДК [355.34:94](477) «1941-1945»

ВЄДЄНСЄВ Д.В.

СЛЮСАРЕНКО А.В.

\title{
СПЕЦІАЛЬНИЙ ОРГАН 3 КООРДИНАЦІЇ РОЗВІДУВАЛЬНО-ДИВЕРСІЙНОЇ ДІЯЛЬНОСТІ НА ОКУПОВАНІЙ ГІТЛЕРІВСЬКИМИ АГРЕСОРАМИ ТЕРИТОРІЇ УКРАЇНИ: ІСТОРИЧНИЙ ДОСВІД
}

У статті на основі широкого кола маловідомих або не залучених до наукового обігу документів радянських спецслужб та партизанського руху досліджуеться та узагальнюеться повчальний для Сил спеціальних операцій Збройних Сил сучасної України історичний досвід створення та оперативно-бойової діяльності державного органу 3 розгортання й координації опору гітлерівським загарбникам на окупованій території України у 1941-1944рр. Розглядаються функції, структура, форми і методи роботи 4-го Управління НКВС-НКДБ Української РСР, на яке покладалася зафронтова розвідувальнодиверсійна робота. Вивчається роль спецслужби в розвідувальному й контррозвідувальному забезпеченні партизанського руху.

Ключові слова: воєнно-історичний досвід, спеціальні підрозділи, розвідка, контррозвідка, партизанський рух, диверсії.

Актуальність тели. 7 липня 2016 р. Верховна Рада України ухвалила Закон України «Про внесення змін до деяких законів України щодо Сил спеціальних операцій Збройних Сил України», що створило належні базові нормативно-розпорядчі умови для цілеспрямованої розбудови Сил спеціальних операцій (CCO) як самостійного компоненту Збройних Сил України. Реалізація норм

Веденеев Дмитро Валерійович, доктор історичних наук, професор, провідний науковий співробітник науково-дослідної лабораторії (військово-історичних досліджень) Наукового центру Сухопутних військ, Національна академія сухопутних військ імені гетьмана Петра Сагайдачного, м. Львів.

Слюсаренко Андрій Віталійович, кандидат історичних наук, доцент, заступник начальника Національної академії сухопутних військ імені гетьмана Петра Сагайдачного з наукової роботи, м. Львів.

(C) Веденеев Д.В., Слюсаренко А.В., 2017 
згаданого Закону дозволить підвищити бойовий потенціал армї за рахунок наявності в ї складі дієвого інструменту воєнно-силового стримування можливої збройної агресії чи збройного конфлікту, підвищить можливості держави щодо проведення спеціальних заходів, у тому числі поза межами України, дозволить досягати воєнно-політичні і воєнно-стратегічні цілі та припиняти конфлікти на ранній стадії виникнення. Згаданий акт відніс до сфрери компетенції ССО участь в організації «руху опору» (тобто партизансько-підпільної боротьби у разі окупації території України), що вельми актуалізувало завдання дослідження й творчого використання повчальної історичної спадщини - як творення «елітних військ» провідних держав світу, так і всебічного, позбавленого легковажних кон'юнктурних забобонів вітчизняного досвіду творення спецпідрозділів, які здійснювали розвідувально-диверсійне та інше специфічне оперативно-бойове забезпечення діючої армії.

На думку спеціалістів, вивчення діяльності держави, їі збройних сил та спецслужб із організації опору противнику на окупованій території, включаючи розгортання партизанства, є одним із перспективних напрямів наукового забезпечення підготовки військових фрормувань України до дій в особливий період [1]. Значні пізнавальні можливості тут відкриває неупереджене вивчення досвіду спеціального органу із координації розвідувально-диверсійної роботи та оперативного забезпечення партизанського руху на окупованій гітлерівцями території СРСР та Української PCP у 1941-1944 pp.

У вітчизняній історіографбї тели статті виокремлюється низка провідних напрямів:

спеціальні дослідження співробітників радянських спецслужб та військ спецпризначення, створені для урахування досвіду зафрронтової розвідувально-диверсійної та контррозвідувальної роботи 1941-1945 pp. у разі глобальної війни та у локальних конфліктах [2-6 та інші];

закриті на той час праці з історії спеціальної зафронтової діяльності органів держбезпеки [7-10 та інші]; 
відкриті наукові та науково-популярні (пропагандистські) роботи радянських дослідників минулого спецслужб та партизанства [11-14 та інші];

дослідження сучасних українських авторів, для яких властиве широке введення до наукового обігу раніш засекречених матеріалів, відмова від ідеологічних кліше та науково-аналітичне узагальнення історичного досвіду зафронтової спеціальної діяльності, яке корелюється із потребами інтелектуального забезпечення оборонного будівництва в Україні [15-20 та інші].

Відповідно, метою иієё статmі є виявлення історичного досвіду творення, форм i методів діяльності спеціального органу із розгортання розвідувальнодиверсійної діяльності на окупованій території України в період Другої світової війни.

Виклад основного матеріалу. Розвідувально-диверсійна та оперативно-бойова діяльність за лінією фронту («зафронтова діяльність), або оперативна робота на окупованій території) 3 перших днів війни почала організовуватися й розвиватися як самостійний напрям зусиль органів державної безпеки, спрямований на відсіч агресору. Завдання здобування розвідувальної інформації на зайнятій противником території (а також на території

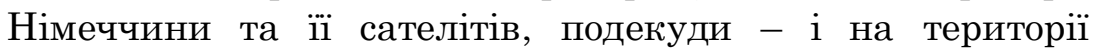
формально нейтральних держав), усебічної дестабілізації ворожого тилу потягло за собою необхідність творення спеціальних фрункціональних підрозділів із керівництва, координащії та безпосереднього розгортання зафронтової роботи.

Першим подібним органом на рівні союзного Центру стала Особлива група при народному комісаріаті внутрішніх справ СРСР, створена наказом останнього від 5 липня 1941 р. № 00882. Група негайно розпочала формування резидентур, агентурних груп та агентіводинаків для виконання спеціальних завдань за лінією фрронту, а також для залишення їх на осілість в окремих містах і місцевостях, яким загрожувала окупація. 
У жовтні 1941 р. військові підрозділи при згаданій Особливій групі НКВС об'єднали в Окрему мотострілецьку бригаду особливого призначення (ОМСБОП) у складі двох полків, саперно-підривної роти, роти зв'язку, окремих загонів спецпризначення, школи молодшого командного складу та спеціалістів, в яких служили виключно добровольці (покликані сприяти розгортанню партизанського руху, широких диверсійних дій на комунікаціях противника, веденню стратегічної й тактичної агентурної розвідки).

Водночас давалось взнаки те, що учасники оперативних груп нерідко підбиралися без належної перевірки їх стійкості, придатності до суворих зафронтових умов, не отримували належної спецпідготовки, навичок конспірації, слабко проводилося і попереднє вивчення становища у місцях висадки зафронтових груп і контррозвідувальнополіцейського режиму противника у місцевостях дій зафрронтових груп, бракувало далекосяжних засобів зв'язку, спеціального обладнання й амуніції тощо. Спецслужбам Німеччини й Румунї вдалося створити агентурні позиції у радянському підпіллі, ставалися й випадки добровільної зради або фізичного зламання захоплених ворогом учасників підпілля. Зокрема, зрада серед співробітників та агентів розвідувально-диверсійних резидентур у Києві, Одесі, Миколаєві призвела до розгрому нелегальних резидентур НКВС, загибелі їх керівників.

Вже 3 кінця серпня 1941 р. Особлива група та ОМСБОП розпочали формування спеціальних опергруп та загонів для відправлення в тил ворога (3-20 учасників 3 радіостанціями, мінно-вибуховими засобами, документами прикриття). У міру збільшення окупованої території та масштабів розвідувально-диверсійної діяльності у запіллі ворога, на основі Особливої групи наказом НКВС СРСР від 3 жовтня 1941 р. № 001435 створили 2-й відділ НКВС СРСР із безпосереднім підпорядкуванням главі відомства. 18 січня 1942 р. 2-й відділ НКВС СРСР реорганізували в 
4-те Управління (зафронтова робота) НКВС СРСР на чолі із генералом П. Судоплатовим (iз відтворенням Наркомату державної безпеки СРCP у 1943 р. цей підрозділ перейшов до складу НКДБ СРСР та відповідних союзних республік). «Руйнування тилів ворога та організація агентурної розвідки на окупованій противником території» - так у службових документах стисло визначалася місія зафронтового управління [21, с. $258 ; 22$, т. 46 , арк. 1].

Згадані 4-ті підрозділи НКВС-УНКВС-НКДБ-УНКДБ та їх зафронтові формування упродовж війни слугували провідним інструментом таємного протиборства 3 агресором (у квітні 1942 р. 4-й відділ НКВС УРСР був реорганізований у 4-те Управління). Наказ НКВС СРСР від 25 серпня 1941 р. № 001151 покладав на 4-ті відділи НКВС-УНКВС, зокрема, організацію партизанського руху у прифронтових областях.

Відповідно до нормативного документа 4-ті підрозділи НКВС-УНКВС мали здійснювати організацію агентурної та військової розвідки в районах вірогідних дій партизанських загонів та диверсійних груп в тилу противника, керувати діяльністю диверсійних груп, проводити розвідувальне опитування військовополонених, взаємодіяти при цьому 3 органами військової контррозвідки НКВС, армійським командуванням, партійними організащіями та органами влади [21, с. 257-258].

Затверджене Наказом НКВС СРСР від 1 червня 1942 р. № 001124 «Положення про роботу 4-х відділів НКВС-УНКВС республік, країв і областей» покладало на них фрункцію «організації та керівництва агентурнорозвідувальною і диверсійною діяльністю в тилу противника», збирання військово-політичної інформації про становище на окупованій території. Серед провідних завдань спецпідрозділу визначалися:

- створення нелегальних резидентур в населених пунктах на окупованій території та забезпечення надійного зв'язку з ними; 
- відновлення взаємодії з найбільш цінною та перевіреною агентурою на окупованій території;

- запровадження агентури в розвідувальні, адміністративні органи противника та антирадянські організації;

- підбір та перекидання за лінію фрронту кваліфікованої агентури та просування їі до Німеччини та інших европейських країн;

- формування та направлення за лінію фрронту розвідувально-диверсійних груп, маршрутної агентури;

- забезпечення зафронтових фрормувань зброєю, диверсійними засобами, засобами зв'язку тощо.

Пропонувалась структура апарату 4-х підрозділів (відділів):

- 1-ше відділення: запровадження та керівництво діяльністю агентурою в розвідувальних та адміністративних органах противника, антирадянських організаціях, підбір негласних оперативних джерел для виведення на територію держав-противників;

- 2-ге відділення: створення нелегальних резидентур у важливих населених пунктах на окупованій території, відновлення зв'язку із раніш залишеною там агентурою НКВС, агентурна робота на найбільш потенційно загрозливих напрямках;

- 3-те відділення: формування та керівництво роботою розвідувально-диверсійних та спеціальних груп;

- 4-mе відділення: матеріально-технічне забезпечення розвідувально-диверсійної роботи, оперативна техніка тощо;

- Секретаріат, облікова група [23, спр. 102, арк. 67-69 зв.].

Безпосередньо у складі 4-го Управління НКВС УРСР перший відділ займався розвідувально-диверсійною роботою на теренах країн-сателітів Німеччини, або окупованих нею країн Східної Свропи; другий організовував зафронтову роботу на тимчасово окупованій території; третій займався розгортанням партизанських формувань та їх оперативним забезпеченням (до передачі партизанських формувань у підпорядкування Українському штабу партизанського руху у липні 1942 р.). 
На першому етапі війни наголос було зроблено на розгортанні агентурної мережі, що мала діяти в тилу агресорів, котрі до кінця 1941 р. окупували більшу частину території України. У 1941-1942 рр. на залишеній території осіло 12726 оперативних джерел НКВС УРСР, в т.ч. 43 резиденти та 644 агентів, 41 диверсійна група (502 особи), 1367 розвідників-одинаків, 1901 утримувач конспіративних квартир, 77 зв'язкових (до 1944 р. загальна кількість залишених i виведених за лінію фронту негласних помічників досягла майже 17 тис. осіб) [22, т. 46, арк. 26-27]. Із більшістю з них зв'язок відновити не вдалося, адже жорсткий контррозвідувальний режим та інші обставини не дозволи багатьом 3 негласних помічників працювати за призначенням.

Поступово виявлялися, аналізувалися прорахунки й недоліки в організації зафронтової роботи, вживалися заходи 3 їх усунення. Так директива НКВС CPCP від 10 лютого 1943 р. № 48 вказувала, що основними недоліками в організації підготовки та закидання агентури за фронтову смугу можна вважати незадовільну перевірку та поверхову підготовку оперативних джерел; недостатньо забезпечений зв'язок, нестачу радіозасобів, внаслідок чого із більшістю зафронтових джерел не існувало обміну інфрормацією; постановку агентурі надто масштабних, нереалістичних для виконання завдань; відсутність належної централізації у справі виведення негласних помічників на окуповану територію. Відтак пропонувалося зосередити роботи з виведення агентури в тил противника виключно в 4-х підрозділах НКВС (виведення агентури іншими оперативними підрозділами мало б здійснюватися у порозумінні та засобами 4-го Управління - 4-х відділів НКВС). Уточнювалися основні завдання зафронтової розвідувальної діяльності, які ставилися перед негласним складом НКВС:

- збір інформації про агентуру спецслужб агресорів, закинутих у радянський тил, або залишену на радянській території при відступі; 
- запровадження перевіреної агентури НКВС в розвідувальні, контррозвідувальні, адміністративні органи окупаційної влади, антирадянські організації тощо;

- вивчення контррозвідувального режиму противника, здобуття зразків документів, квитків, перепусток тощо для легалізації радянських розвідників на окупованій території;

- вербування на окупованих теренах конфіденційних джерел серед персоналу окупаційної адміністрації, проникнення в агентурний апарат спецслужб ворога, формування колаборантів тощо [24, ч. 2, арк. 1-2].

Залишені на окупованій території розвідувальні групи вдалися до творення резидентур та підпільної мережі 3 метою збору значущої інформації та дестабілізації тилу противника, перешкоджали йому використовувати економічний потенціал України.

В ході війни і в залежності від зміни стратегічної та оперативної обстановки, потреб Діючої армії розпорядчими документами корегувалися i завдання 4-го Управління НКВС-НКДБ УРСР. Так перехід Червоної Армї в стратегічний наступ із звільнення України від гітлерівців викликав необхідність активізації диверсійної роботи в тилу противника. Відповідно, виходячи із настанов 4-го Управління НКДБ СРСР 4-те Управління НКДБ УРСР видало 20 серпня 1943 р. вказівку щодо пожвавлення диверсійної роботи на окупованій території. Приписувалося у 45-х підрозділах НКВС-УНКВС УРСР створити групи 3 2-3 співробітників для організащії диверсій на важливих залізничних комунікаціях, промислових та військових об'єктах.

Ставилося завдання вербування спеціально підготовлених, рішучих агентів та агентурних груп для їх виведення в тил противника. Наголошувалося на необхідності підбору агентів-вербувальників із зв'язками серед персоналу залізниць та промислових підприемств, здатних виводити з ладу комунікації, мости, ешелони, склади, бази пально-мастильних матеріалів, військові 
заводи тощо. Відповідно, у розпалі титанічної битви за Дніпро диверсанти вивели 3 ладу чимало військових об'єктів противника, активно діяли на комунікаціях, полегшуючи наступ фронтів.

Зрозуміло, що протиборство із досвідченими, кваліфікованими спецслужбами ворога, з урахуванням певних прорахунків в організації зафронтової роботи, негативного впливу передвоєнних репресій та кадрових «чисток» в органах держбезпеки давалося дорогою ціною. Так із виведених за окуповану територію у 1941-1942 рр. 4-м Управлінням НКВС УРСР 595 розвідувальних груп та 2027 розвідників-«одинаків» на «велику землю» повернулося лише 34 групи та 400 «одинаків» [25, с. 93]. Загалом упродовж війни загинуло 489 (з них 42 радисти) та зникли безвісти 271 кадрових співробітників та агентів 4-го Управління НКВС-НКДБ УРСР [22, т. 46, арк. 36, 41].

Позитивні зміни у становищі на фронтах, міжнародній та військово-політичній обстановці в СРСР, поступове звільнення окупованої території призводили і до корегування функцій та структури 4-го Управління, тепер вже у складі Наркомату державної безпеки УРСР. Станом на жовтень 1943 р. організаційно-фрункціональна структура Управління виглядала таким чином:

- перший відділ: керівництво оперативними групами в тилу противника, запровадження агентури в розвідувальні й контррозвідувальні органи, адміністративно-політичні установи противника на окупованій територіі, створення оперативних позицій у підпіллі ОУН, в Російській визвольній армії («власовці»), робота у середовищі «церковників і сектантів»;

- другий відділ: організація диверсійно-терористичної роботи, ведення розслідування за фрактами зради агентури 4-го Управління, допит військовополонених, керівництво 4-ми підрозділами УНКДБ;

- mретій відділ: матеріально-технічне забезпечення агентурно-оперативної роботи, оперативний облік, інформаційна робота, оперативна техніка та виготовлення документів прикриття [24, ч. 1, арк. 18-21]. 
До основних видів зафронтових оперативних формувань НКВС-НКДБ відносилися:

- агентурно-оперативні групи (3-5 агентів органів держбезпеки, що пройшли певну підготовку для дій у близькому тилу з розвідувальними завданнями;

- оперативно-чекістські групи (5-8 кадрових співробітників держбезпеки, які виводилися за лінію фронту для організації розвідувально-диверсійної роботи 3 позицій, як правило, партизанських загонів);

- оперативно-чекістські групи спеціального призначення (10-15 і більше співробітників НКВС-НКДБ, виведених на територію іноземних держав для виконання спеціальних розвідувально-диверсійних завдань);

- оперативно-чекістські бази (озброені загони 3 кадрових співробітників, агентів спецслужби, партизан, чисельність до 100 i вище осіб, які вели активну диверсійно-терористичну боротьбу на комунікаціях, проти важливих об’ектів противника тощо).

Опергрупи включали командира, його заступника 3 розвідувально-диверсійної роботи, комісара, 1-2 радистівшифрувальників, медпрацівників, оперативних працівників, перевірених агентів. Загалом НКВС-НКДБ УРСР за роки війни створили 135 подібних формувань (7500 учасників) [8, с. 2 ; 26, с. 93$]$.

Серед провідних завдань зафронтових оперативних формувань можна визначити:

в області розвідувальної роботи: збір та передача командуванню Червоної Армії інформації про дислокацію, чисельність, озброення, штаби військ противника, систему постачання, а також про спеціальні, каральні, адміністративні органи окупаційного режиму, формування колаборантів тощо;

стосовно диверсійної роботи: порушення нормальної роботи прифронтових i тилових комунікацій ворога, виведення з ладу військових і промислових об’ектів, запасів стратегічних матеріалів, організація спецпропаганди тощо;

в області контррозвідувальної роботи: виявлення та вивчення форм і методів роботи органів розвідки та контррозвідки агресорів, їх карально-поліцейських структур, 
запровадження в них власної агентури, розклад зсередини пронімецьких формувань колаборантів, контррозвідувальний захист партизанських формувань тощо.

Підготовка, злагодження, екіпіювання, виведення за лінію фронту, адаптація до діяльності в тилу противника, налагодження зв'язку i поточне керівництво роботою оперативних формувань, постачання, їх подальше виведення на «Велику землю» являло собою достатньо складний комплекс заходів, який забезпечувався силами 4-го Управління НКВС-НКДБ УРСР. Було зміцнено і матеріально-технічну базу зафронтової роботи підготовлено понад 150 кваліфікованих радистів, відкриті потужні радіовузли з модернізованою технікою у Києві та Львові для далекого зв'язку із зафронтовими фрормуваннями [22, т. 46, арк. 41].

Результативністю відзначилися зафронтові формування НКДБ УРСР «Переможці» Д. Медведєва, «Унітарці» В. Хондожка, «Дружба» М. Онищука, «Розгром» Г. Бурлаченка, «Волинщі» П. Форманчука і багато інших. Відома звитяга загону особливого призначення «Переможці» під командуванням Героя Радянського Союзу полковника Д. Медведева. До березня 1944 р. його підлеглі витримали 92 бої з елітними частинами противника (Берлінськими поліцейськими полками, а також відомою з придушення Варшавського повстання бригадою СC Дерливангера), знищили понад 2 тис. гітлерівців і 6 тис. бійців ворожих допоміжних формувань й колаборантів, підірвали 81 ешелон 3 живою силою і технікою. Ними ж здобуті вельми цінні дані про підготовку деблокади армї Паулюса під Сталінградом, перекидання резервів вермахту з Свропи i Північної Африки, наступ на Курській дузі, розробку крилатих ракет «Фау».

Загалом за роки війни органи держбезпеки вивели за лінію фронту 2222 оперативні групи (з яких НКВС-НКДБ УРСР сорормували 677). Від них було отримано 4418 цінних розвідувальних повідомлень про становище за смугою фрронту, з яких 1358 скерували до Генерального штабу Червоної Армії, 420 - командуванню фрронтів, 629 командуванню авіації далекої дії для завдання бомбових 
ударів. Щоб рельєфніше подати ефективність зафронтової роботи, наведемо такі дані: 3 початку 1944 р. і до кінця війни бійцями спеціальних підрозділів республіканського НКДБ знищено або виведено з ладу 22,5 тисячі гітлерівців, узято в полон до 10 тисяч, висаджено 20 військових підприемств, 18 складів, 9 бронепоїздів, 100 гармат, 207 військових ешелонів, 110 мостів, знищено понад 106 танків і 675 автомашин [27; 28, с. 90; 29, с. 129].

Загальний внесок у перемогу над гітлеризмом опергруп, спеціальних загонів та інших фрормувань 4-го Управління НКВС-НКДБ УРСР за роки війни становив 26 тис. вбитих i поранених, 3329 полонених, 6747 роззброєних вояків противника, 25 знищених генералів i високих чиновників окупаційної адміністрації, 121 співробітник спецслужб Німеччини та ї союзників. Було виведено з ладу 15 військових заводів і 23 підприемства, 6 електростанцій, 27 складів, 92 залізничних мости, 41 шосейний міст. Підірвано 242 ешелонів (311 паротяг, до 2500 вагонів), 5 бронепотягів і платформ, знищено 43 літаки, 135 танків, 115 гармат і мінометів [22, т. 46, арк. 43-45].

Налагоджена органами державної безпеки система розвідувальної та контррозвідувальної роботи з позицій партизанського руху в Україні стала помітним чинником бойових успіхів Червоної Армії із вигнання агресорів. За оцінками начальника Головного розвідувального управління Червоної Армії генерал-лейтенанта Ільїчова (вересень 1944 р.), здобуті партизанською розвідкою відомості щодо збройних сил противника кваліфікувалися як «вельмі цінні», такі, що у більшості випадків підтверджувалися ходом подій [30, спр. 275, арк. 102].

Таким чином, діяльність спеціального координаційного органу сприяла розвідувальному забезпеченню Діючої армії, розгортанню партизанського руху (насамперед організації його розвідувальної роботи та контррозвідувального захисту), підриву військово-економічного потенщіалу противника, сприяла проведенню інших важливих оперативних заходів органів держбезпеки, в тому числі формуванню агентурної мережі за кордоном. 
1. Биструхін Г.С. Діяльність спецпідрозділів органів державної безпеки у Великій Вітчизняній війні та використання їх досвіду в сучасних «гарячих точках» // Сторінки воєнної історії України. - К., 2002. - Вип. 6. - С. 114-119.

2. Андрианов В.Н. Партизанская борьба в современных войнах. - М., 1988. - 214 c.

3. Андрианов В.Н. Участие чекистов в партизанской борьбе в годы Великой Отечественной войны. - М.: ВКШ КГБ СССР, 1990. - 116 с.

4. Боярский В.И. Партизанская борьба в годы Великой Отечественной войны и участие в ней органов и войск государственной безопасности. - M.: Краснознаменный институт повышения квалификации офицерского состава Пограничных войск КГБ СССР, 1991. - Ч. 1. - 291 с.: Ч. 2. - 243 с.

5. Брайко П.Е., Старинов И.Г. Партизанская война. M.: B/ч 64510, 1983. - Ч. 1. - 335 c.

6. Зафронтовая работа оперативных групп органов государственной безопасности. - М.: ВКШ КГБ CCCP, 1989. - 217 c.

7. Иванков А.В. Деятельность органов государственной безопасности Украинской ССР в годы Великой Отечественной войны (1941-1945 гг.): Автореф. дисс. канд. юрид. наук. - М.: ВКШ КГБ при СМ CCCP, 1983. - 26 c.

8. Коровин B.B. Деятельность оперативных групп органов государственной безопасности в тылу противника в годы Великой Отечественной войны и использование их опыта в будущей войне: Авторедр. дисс. канд. юрид. наук. - М.: ВШ КГБ при СМ CCCP, 1964. $-18 \mathrm{c}$.

9. Селенов Я.Ф. Некоторые вопросы агентурной разведки оперативных групп органов государственной безопасности в тылу противника на территории сопредельных с СССР стран в годы Великой Отечественной войны (1941-1945 гг.) // Труды ВКШ КГБ СССР. - 1985. - № 35. - С. 70-84.

10. Калиниченко О.Н. Боевая и политическая деятельность пограничных войск на территории Украинской ССР в период Великой Отечественной войны: Авторедр. дисс. канд. истор. наук. - К.: Институт истории АН УССР, 1980. - 24 с. 
11. Старожилов Н.В. Партизанские соединения Украины в Великой Отечественной войне. - К.: Вища школа, 1983. - 237 с.

12. Мищенко Г.П., Мигрин Г.П. Задача особой важности (Партизанская разведка. 1941-1945 гг.). - К.: Вища школа, 1985. - 206 с.

13. Куманев Г.А., Чайковский А.С. Чекисты стояли насмерть. - К.: Политиздат Украины, 1986. -237 с.

14. Курас И.Ф., Кентий А.В. Штаб непокоренных (Украинский штаб партизанского движения в годы Великой Отечественной войны). - К.: Политиздат Украины, 1988. - 330 с.

15. Кентій А., Лозицький $B$. Війна без пощади i милосердя: партизанський фрронту тилу вермахту в Україні (1941-1945). - К.: Генеза, 2005. - 408 с.

16. «Создавать невыносимые условия для врага и всех его пособников...». Красные партизаны Украины, 1941-1944: малоизученные страницы истории. Документы и материалы / Авторы-составители Гогун А., Кентий А. - К.: Украинский издательский союз, 2006. - $430 \mathrm{c}$.

17. Чайковський А.С. Айсберг. 3 історії органів внутрішніх справ i державної безпеки. - К.: Парламентське видавництво, 2013. - С. 453-505.

18. Ведєнєев Д.В. Радянські спецслужби в України в роки Другої світової війни // Україна в Другій світовій війні: погляд з XXI ст. Історичні нариси. - К.: Наукова думка. - 2011. - Книга друга. - С. 279-310.

19. Веденєев Д.В. Діяльність органів та військ державної безпеки в Україні в період Другої світової війни (1939-1945рр.). - К.: НВВ НА СБУ, 2011. -98 c.

20. Ведєнєев Д. Розвідувально-диверсійна та контррозвідувальна діяльність органів державної безпеки за лініею фронту в 1941-1945 pp. (за документами НКВС-НКДБ Української РСР) // 3 архівів ВУЧК-ГПУ-НКВД-КГБ. - 2014. - № 2. C. $291-352$.

21. Советские органы государственной безопасности в Великой Отечественной войне. Сборник документов и материалов. - М., 1985. - T. II. - 640 с.

22. Галузевий державний архів СБ України (ГДА СБУ). - Ф. 60. - Спр. 86751. 
23. Галузевий державний архів MBC України. Ф. $45 .-$ Оп. 1.

24. ГДА СБУ. - Ф. 60. - Спр. 83529.

25. Національна академія СБ України. - Один. збер. № 6437.

26. Иванков А.В. Материалы к лекции по истории советских органов госбезопасности. - К.: ВК КГБ CCCP, 1974. $-118 \mathrm{c}$.

27. ГДА СБУ. - Ф. 13. - Спр. 375.

28. Никитченко В.Ф. Чекисты Украины в период Великой Отечественной войны // Труды ВКШ КГБ при СМ СССР. - 1971. - № 2. - С. 79-85.

29. Борисов И. Оперативные группы во вражеском тылу // Сборник КГБ при СМ СССР. - 1968. - № 4. C. $128-134$.

30. Центральний державний архів громадських об’еднань України. - Ф. 62. - Оп. 1.

Надійшла до редколегії 12.12.2016 p.

Рецензент: O.M. Сухий, доктор історичних наук, професор, завідувач кафедри новітньої історії України, Львівський національний університет імені Івана Франка, м. Львів. 
Веденеев Д.В., Слюсаренко А.В.

СПЕЦИАЛЬНЫЙ ОРГАН КООРДИНАЦИИ РАЗВЕДЫВАТЕЛЬНО-ДИВЕРСИОННОЙ ДЕЯТЕЛЬНОСТИ НА ОККУПИРОВАННОЙ ГИТЛЕРОВСКИМИ АГРЕССОРАМИ ТЕРРИТОРИИ УКРАИНЫ: ИСТОРИЧЕСКИЙ ОПЫТ

В статье на основе широкого круга малоизвестных или не введенных в научный оборот документов советских спецслужб и партизанского движения исследуется и обобщается поучительный для Сил специальных операций Вооруженных Сил современной Украины исторический опыт создания и оперативно-боевой деятельности специализированного органа по развертыванию и координации сопротивления гитлеровским захватчикам на оккупированной территории Украины в 1941-1944 гг. Рассматриваются функции, структура, формы и методы работы 4-го Управления НКВД-НКГБ Украинской СCP, на которое возлагалась зафронтовая разведывательно-диверсионная работа. Исследуется роль спецслужбы в разведывательном и контрразведывательном обеспечении партизанского движения.

Ключевые слова: военно-исторический опыт, специальные подразделения, разведка, контрразведка, партизанское движение, диверсии.

Vyedyenyeyev D., Slyusarenko A.

SPECIAL BODY FOR COORDINATING RECONNAISSANCE AND SABOTAGE ACTIVITIES IN THE OCCUPIED NAZI AGGRESSORS TERRITORIES OF UKRAINE: HISTORICAL EXPERIENCE

On the basis of a wide range of little-known Soviet secret police documents and partisan movement is studied and summarized instructive for special operations forces of modern Ukraine historical experience of combat and operational activities of a public authority on the deployment and coordination resistance to the Nazi invaders occupied territory of Ukraine in 1941-1944. We consider the functions, structure, forms and methods of the 4th departmentNKVD-NKGB of Ukrainian SSR, which was assigned to provide intelligence-subversive work out of front. We study the role of special servicesin the intelligence and counterintelligence support of partisan movement.

Keywords: military and historical experience, special forces, intelligence, counter-intelligence, the partisan movement, sabotage. 